\title{
EVALUATION OF AUTHENTIC ASSESSMENT IMPLEMENTATION IN LEARNING SOCIAL SCIENCE AT SMP NEGERI 2 PURWOKERTO
}

\author{
Mustolikh \\ Universitas Muhammadiyah Purwokerto \\ Indonesia
}

\author{
Suwarsito \\ Universitas Muhammadiyah Purwokerto \\ Indonesia \\ Neneng Kusmijati \\ SMP Negeri 2 Purwokerto \\ Purwokerto, Indonesia
}

\begin{abstract}
This study aimed to figure out: (1) the implementation of authentic assessment in learning social science, and (2) obstacles in the implementation of authentic assessment in SMP Negeri 2 Purwokerto.

This study was an evaluation research with descriptive quantitative approach. Stake Countenance Model was applied as evaluation model of this study. This study was conducted on 5 - 17 June 2017 in SMP Negeri 2 Purwokerto. Subjects of this study were social science teachers and students of class VIII F. Data of this study were collected by using observation, interview, and documentation. Descriptive method was used for analysing the data of the study.

The result showed that: (1) implementation of Stake model authentic assessment planning in input phaseindicated that $85.29 \%$ indicators were implemented by the teachers, and $14,71 \%$ indicators were not yet implemented by the teachers. Achievement level of the assessment in this phase belonged to good category. (2) Implementation of the assessment in process phase indicated that $86,67 \%$ indicators were implemented by the teachers, and $13,33 \%$ indicators were not yet implemented by the teachers. Achievement level of the assessment in this phase belonged to good category, (3) Implementation of the assessment in outcomes phase indicated that 84,72\% indicators were implemented by the teachers, and $15,28 \%$ indicators were not yet implemented by the teachers. Achievement level of the assessment in this phase belonged to good category. (4) Obstacles found in the implementation of the assessment were: (a) complicated planning, (b) many components that must be noticed by the teacherssimultaneously in the implementation of the assessment, (c) detailed attitude assessment addressed to many students. Based on the result of this study, the teachers are expected to complete the unavailable assessment instrument and to have collaborative learning by applying Classroom Action Research.
\end{abstract}

Keywords: Authentic Assessment, Social Science Learning

\section{INTRODUCTION}

The development of curriculum 2013 is implemented due to internal and external challenges faced by Indonesia. The internal challenge of educational demands refers to the 8 National Standard of Education and Indonesian population growth factor. External challenge relates to future challenges, future competencies, community perceptions, knowledge, and pedagogical developments, and various negative phenomena.

The objectives of the curriculum include four competencies, namely (1) spiritual attitude competence, (2) social attitude, (3) knowledge, and (4) skill. The competence is achieved through the learning process of intra-curricular, co-curricular, and/ or extracurricular. Formulation of the spiritual attitude competence is, "Appreciate and live religious teachings that he/ she embraces". Formulation of social attitudes competence is, "Show honest behaviour, discipline, responsibility, care (tolerance, mutual assistance), well mannered, and confident in interacting effectively with his/her surrounding social and natural environment. Both competencies are achieved through indirect teaching, i.e. exemplary, habituation, and school culture by paying attention to the characteristics of subjects, as well as the needs and conditions of learners. The growth and development of attitude competence is done throughout the learning process 
and can be used as teacher consideration in developing the learners' character further.

The development of science, technology, and change of local, national, and international society has become the main foundation in the development of curriculum 2013. In this curriculum, social science subjects should contribute to the formation of the learners' knowledge, attitude and skills as well as the mastery of ICT (Information and Communication Technology) to face global challenges in the $21^{\text {st }}$ century. As part of the world community, learners should understand the environment and society in local, national, and global scope, realize multicultural (multicultural) diversity, develop social skills, and mastering the development of technology.

Social science is one of the compulsory subjects in Junior High School/ MTs integrating geography, sociology, economics, and history. Therefore, social science learning is organized with an interdisciplinary, multidisciplinary or trans-disciplinary approach from the social sciences, humanities, and psychology in accordance with the development of the learners.

Social science uses geography as a platform of assessment considering all places, objects, resources and events tied to the location. The purpose is to emphasize the importance of space as a place to live and resources for human beings to recognize the potential and limitations of space, therefore the spaces are always interconnected (inter-space connectivity) to complement each other. As a result of the interaction between nature and humans, as well as inter-space connectivity, the space always changes with time and technology used by humans in utilizing the space. Understanding of the space within the scope of Indonesia can develop a love of the homeland, and strengthen the unity of Indonesia. Social science learning in SMP / MTs covers the understanding of the environment and society in national and international scope to develop knowledge, attitude, social skill, and the ability to think logically, systematically, critically, and analytically. Those things are necessary not only to enhance the understanding of the potential of Indonesia but also to develop nationalism, to strengthen national attitude, and to be able to work together in a plural society as a part of society, state and world.

Changes in the curriculum 2013 include learning and assessment of learning outcomes. Social science learning is one of the subjects applying scientific approach that facilitates learners in developing logical, critical, rational, and analytical thinking skills. This approach is applied through five steps; observing, asking, gathering information, associating, and communicating. The approach is applied through Problem Based Learning, Project Based Learning, Discovery Learning, and Inquiry Learning. This approach is always contextualized with the conditions of each region and developed through cooperation (cooperative learning). Observation can be done through pictures, maps, graphics, film, and other visualization. Environment becomes a source of learning covering teaching material, learning media, and learning aids. Teachers can use some techniques applied in learning process to enhance students' highorder thinking skill such as question and answer method, discussion, demonstration, role-playing, simulation, debate, etc.

The learning process as a process of instilling spiritual and social attitudes was implemented both indirectly (direct teaching) and directly (direct teaching). Indirect teaching is done through exemplary and school culture. Direct teaching is done through habituation, discipline of completing the task, discussion, and teamwork.

The implementation of Curriculum 2013 is expected to improve Proportional and objective educational assessment standards. Authentic assessment as defined in Permendiknas Number 66 Year 2013 is a comprehensive assessment to assess the input, the process, and the output of learning including assessment of attitude, knowledge, and skills. Authentic assessment gives more focus on assessing the overall results of students' learning because it assesses not only the end result of students' learning but also students' learning progress. Authentic assessment enables teachers to perform various assessment techniques to be able to assess attitude, skill, and knowledge.

The issues related to the implementation of the authentic assessment according to curriculum 2013 are quite broad and complex so that they cannot be studied completely. Therefore, this research focuses on the implementation of authentic assessment consisting of attitude, knowledge, and skill assessment. The implementation of an authentic assessment needs to be evaluated to determine whether curriculum 2013 which requires social science teachers to conduct authentic assessments is well implemented.

Assessment of social science learning outcomes is gathering information process/ authentic proof of students' learning achievement including spiritual, social, knowledge, and skill competencies conducted in a planned and systematic way, during and after the learning process. Assessment of learning outcomes done by teachers functions to monitor learning progress, learning outcomes, and detect the suitability between learning and the students' needs continuously. The assessment of spiritual competence is appreciate and live the religious teachings embraced, and social competence includes honesty, discipline, responsibility, care (tolerance, mutual assistance), well mannered, and confident. The assessment can be conducted through observation, self-assessment, and peer assessment. The assessment of knowledge competence is conducted through tests, assignments, and portfolios. Knowledge that must be mastered by 
students are the understanding of definition, concepts, causation, problem identification, and problem solving related to the learning materials. Skill assessment is conducted through portfolio techniques, performance, tasks, exhibitions, demonstrations, both individually and in groups.

Research conducted by Yuli Setyo Dewi, Sarwono, Singgih Prihadi in Journal of Geography Education. Volume 3 No. 1 Year 2014, showed that the implementation of authentic assessment was able to improve students' spatial ability in geography learning on relationship of human and environment as the impact of the hydrosphere dynamics materials in social class X of SMA 7 Surakarta.

The result of the research conducted by Ela Purwanti entitled "Evaluation of Authentic Assessment in Economic Learning based on Curriculum 2013 in SMA Negeri 2 Ngaglik" showed that the implementation of this assessment in in the school was conducted quite well. It was proven by data showed that $79.16 \%$ indicators of this assessment were implemented but $20.84 \%$ indicators of this assessment were not implemented yet.

Based on interviews with social science teachers of SMP 2 Negeri Purwokerto indicated that they had received training curriculum 2013. In addition, learning and assessment of curriculum 2013 were implemented in the school. Learning outcomes assessment updated by curriculum 2013 must be implemented based on Kemendikbud No. 104 Year 2014. Therefore, researchers are interested in conducting this study to find out the suitability between authentic assessment implementation in social science learning with the standard of authentic assessment of curriculum 2013 by taking the title "Evaluation of Authentic Assessment in Social Science Learning in SMP Negeri 2 Purwokerto".

Authentic assessment becomes one of the emphasis in curriculum 2013. Kunandar (2014: 35) reveals that through this curriculum, authentic assessment becomes a serious emphasis in which teachers must apply authentic assessment in every learning process. M. Hosnan (2014: 387) explains that authentic assessment is necessary for the teachers to find out whether the students study seriously, whether the students' learning experience gives a positive influence on students' improvement both intellectual and mental of the students. Udin Syaefudin Sa'ud (2013: 172) explains that authentic assessment is the process by which teachers collect information about students' learning progress. Authentic assessment is a very important and necessary assessment for teachers. Kunandar (2014: 10) also reveals that the assessment aims to measure the success of learning conducted by teachers and the success of students in mastering the determined competencies simultaneously. Teachers can reflect and evaluate the quality of learning done through assessment activities.
Imas Kurinasih and Berlin Sani (2014: 51) explains that the authentic assessment of students includes the competence of attitude, knowledge, and skill performed in a balanced manner. Kunandar (2014: 52) also states that the students' authentic assessment includes attitude, knowledge, and skill competencies. The opinions of the experts are supported by the Attachment of Permendikbud Letter No. 104 of 2014 on the Assessment of Learning Outcomes by Teachers in Primary and Secondary Education stating that the scope of authentic assessment includes the attitude competence (spiritual and social), knowledge, and skills.

Curriculum 2013 applies authentic assessment to assess students' learning progress including attitudes, knowledge, and skills. A Copy of Appendix of Permendikbud Number 104 of 2014 on the Assessment of Learning Outcomes by Teachers in Primary and Secondary Education states that observation, self-assessment, peer assessment, and journal assessment are several ways that can be used to assess students' attitude. In addition, it reveals that performance/ practice, project, written product, and portfolio can be used to assess students' skill. A copy of Appendix Permendikbud Number 66 of 2013 on Standard of Education Assessment states that written tests, oral tests, and assignments can be used to assess students' knowledge.

\section{METHOD}

This study was an evaluation research with descriptive quantitative approach. The evaluation model used was Stake's Countenance Model. Stake identifies 3 (three) stages of the evaluation of education program and the influencing factors of the evaluation called input (antecedents), processes (transactions), and outcomes. Each stage was divided into two stages: description and judgment. The research was conducted on 5 - 17 June 2017 in SMP Negeri 2 Purwokerto. The subjects of this study were social science teachers and students of class VIII F.

This study used techniques for collecting the data. (1) Observation was used to obtain data related to the implementation of authentic assessment in social science learning. The instrument used in this technique was observation sheet. This technique was used in process/ implementation phase (transactions) of the evaluation described by the implementation of learning assessment. (2) Interview was used to obtain data about students' responses to authentic assessment, obstacles, and the process of assessment as well as score calculation in the implementation of this assessment. (3) Documentation study was used to collect documents related to this study such as lesson plan, syllabus, assessment instruments, and students' score documentation. This technique was used in the input phase (antecedents). The assessment points of this phase were the teachers' readiness in implementing the 
assessment and the outcomes phase assessing the authentic assessment management.

Data analysis used in this study was descriptive method. It was done by determining category obtained by each indicator in variable from score calculation and interpreting the scores in sentences.

Table 2.1. Category Classification

\begin{tabular}{|c|c|c|}
\hline No & Average Score & Category \\
\hline 1 & $3,51-4$ & Excellent \\
\hline 2 & $2,51-3,5$ & Good \\
\hline 3 & $1,51-2,5$ & Fair \\
\hline 4 & $1-1,15$ & Poor \\
\hline
\end{tabular}

Source: Permendikbud Number 104 of 2014

\section{RESULTS}

\section{A. Input Phase of Evaluation (Antecedents Phase) 1. Evaluation of Authentic Assessment Planning Implementation}

Description of the implementation of the assessment planning/ preparation conducted by teachers was obtained through document analysis by comparing some indicators that did not yet conformto the standards. More detailed information can be seen in Table 3.1.

Table 3.1. Evaluation of the Implementation of Stake Model Authentic Assessment

Planning in Antecedents Phase

\begin{tabular}{|c|c|c|c|c|c|c|}
\hline \multirow{3}{*}{$\begin{array}{c}\text { Evaluat } \\
\text { ion } \\
\text { Phase }\end{array}$} & \multirow{3}{*}{$\begin{array}{c}\text { Evaluati } \\
\text { on } \\
\text { Compon } \\
\text { ents }\end{array}$} & \multirow{3}{*}{$\begin{array}{l}\text { Numbe } \\
r \text { of } \\
\text { Indicat } \\
\text { ors } \\
\end{array}$} & \multicolumn{4}{|c|}{ Implementation } \\
\hline & & & \multicolumn{2}{|c|}{ Proper } & \multicolumn{2}{|c|}{ Improper } \\
\hline & & & Total & $\%$ & Total & $\%$ \\
\hline \multirow{3}{*}{$\begin{array}{l}\text { Input } \\
\text { Phase } \\
\text { (Antece } \\
\text { dents } \\
\text { Phase) }\end{array}$} & $\begin{array}{l}\text { Attitude } \\
\text { Assessm } \\
\text { ent } \\
\text { Planning }\end{array}$ & 12 & 8 & 66,66 & 4 & 33,34 \\
\hline & $\begin{array}{l}\text { Knowled } \\
\text { ge } \\
\text { Assessm } \\
\text { ent } \\
\text { Planning }\end{array}$ & 12 & 12 & 100 & 0 & 0 \\
\hline & $\begin{array}{l}\text { Skill } \\
\text { Assessm } \\
\text { ent } \\
\text { Planning }\end{array}$ & 10 & 9 & 90 & 1 & 10 \\
\hline \multicolumn{2}{|c|}{ Total } & 34 & 29 & 85,29 & 5 & 14,71 \\
\hline
\end{tabular}

Source: Research data analysed in 2017

The implementation of the assessment planning in this phase based on Table 3.1 can be evaluated or analysed as follows:

a. Evaluation result of the implementation of the attitude assessment planning obtained $66,66 \%$ or 8 indicators of this assessment were implemented by teachers, and $33,34 \%$ or 4 indicators were not yet implemented by the teachers. Four indicators that were not yet implemented were: (1) assessment design which should be written in the syllabus consisting of the assessment technique and the time / period of assessment for each subject matter, (2) indicator which should be formulated using the operational verb, (3) scoring rubric showing a procedure to give scores and to calculate the final score, and (4) assessment criteria showing the achievement score in the form of predicate.

b. The evaluation result of the implementation of knowledge assessment planning obtained 100\% percentage indicated that all the indicators of the assessment were implemented by the teachers.

c. Evaluation result of skill assessment planning obtained $90 \%$ or 9 indicators of this assessment were implemented by the teachers, and $10 \%$ or 1 indicator was not yet implemented by the teachers stating that every basic competence should be developed into two or more indicators based on the discussion depth of basic competence.

The evaluation result of assessment planning implementation in this phase based on table 3.1 indicated that $85.29 \%$ or 29 indicators were implemented by the teachers while $14.71 \%$ or 5 indicators were not yet implemented by the teachers.

2. Achievement Rate Category of Authentic Assessment Planning

The achievement level of this assessment planning were categorized into 4 categories; excellent, good, fair, and poor. Each category was indicated by the percentage obtained from the average score. Each evaluated indicator was rated on a scale of 1 to 4 . More detailed data can be seen in Table 3.2.

Table 3.2. Achievement Rate Category of Authentic Assessment Planning in Input Phase (Antecedents Phase)

\begin{tabular}{|c|l|c|c|c|c|}
\hline No & $\begin{array}{c}\text { Evaluation } \\
\text { Components }\end{array}$ & $\begin{array}{c}\text { Number of } \\
\text { Indicators }\end{array}$ & $\begin{array}{c}\text { Obtained } \\
\text { Total } \\
\text { Score }\end{array}$ & $\begin{array}{c}\text { Average } \\
\text { Score }\end{array}$ & $\begin{array}{c}\text { Categ } \\
\text { ory }\end{array}$ \\
\hline 1 & $\begin{array}{l}\text { Attitude } \\
\text { Assessment } \\
\text { Planning }\end{array}$ & 12 & 32 & 2,6 & Good \\
\hline 2 & $\begin{array}{l}\text { Knowledge } \\
\text { Assessment } \\
\text { Planning }\end{array}$ & 12 & 48 & 4 & $\begin{array}{c}\text { Excell } \\
\text { ent }\end{array}$ \\
\hline $\begin{array}{l}\text { Skill } \\
\text { Assessment } \\
\text { Planning }\end{array}$ & 10 & 36 & 3,6 & $\begin{array}{c}\text { Excell } \\
\text { ent }\end{array}$ \\
\hline Input Phase & $\mathbf{3 4}$ & $\mathbf{1 1 6}$ & $\mathbf{3 , 4}$ & Good \\
\hline
\end{tabular}

Source: Research data analysed in 2017

The achievement level category of the assessment planning in this phase based on table 3.2 can be explained as follows:

a. Achievement level of attitude assessment planning conducted by the teachers in this phase obtained a total score of 32 of 12 indicators with an average score of 2.6which belonged to good category.

b. Achievement level of knowledge assessment planning conducted by the teachers in this phase 
obtained a total score of 48 of 12 indicators with an average score of 4 which belonged to excellent category.

c. Achievement level of skill assessment planning conducted by the teachers in this phase obtained a total score of 36 of 10 indicators with an average score of 3.6 which belonged to excellent category.

The data in Table 3.2 generally indicated that the achievement level of the assessment planning in this phase obtained a total score of 116 of 34 indicators with an average score of 3.4 which belonged to good category.

\section{B. Process Phase of Evaluation (Transaction Phase) 1. Evaluation of Authentic Assessment Implementation}

Description of the implementation of the assessment was obtained through document analysis by comparing several indicators that did not yet confirm to the standards. More detailed data can be seen in Table 3.3.

Table 3.3. Evaluation of Stake Model Authentic Implementation in Phase Process (Transaction Phase)

\begin{tabular}{|c|c|c|c|c|c|c|}
\hline \multirow{3}{*}{$\begin{array}{l}\text { Evaluation } \\
\text { Phase }\end{array}$} & \multirow{3}{*}{$\begin{array}{l}\text { Evalua } \\
\text { tion } \\
\text { Comp } \\
\text { onents }\end{array}$} & \multirow{3}{*}{$\begin{array}{l}\text { Numbe } \\
\text { r of } \\
\text { Indicat } \\
\text { ors }\end{array}$} & \multicolumn{4}{|c|}{ Implementation } \\
\hline & & & \multicolumn{2}{|c|}{ Proper } & \multicolumn{2}{|c|}{ Improper } \\
\hline & & & Total & $\%$ & Total & $\%$ \\
\hline \multirow[t]{3}{*}{$\begin{array}{l}\text { Process } \\
\text { Phase } \\
\text { (Transactio } \\
n \\
\text { Phase) }\end{array}$} & $\begin{array}{l}\text { Attitu } \\
\text { de } \\
\text { Assess } \\
\text { ment } \\
\text { Planni } \\
\text { ng } \\
\end{array}$ & 5 & 4 & 80 & 1 & 20 \\
\hline & $\begin{array}{l}\text { Knowl } \\
\text { edge } \\
\text { Assess } \\
\text { ment } \\
\text { Planni } \\
\text { ng } \\
\end{array}$ & 5 & 5 & $\begin{array}{c}10 \\
0\end{array}$ & 0 & 0 \\
\hline & $\begin{array}{l}\text { Skill } \\
\text { Assess } \\
\text { ment } \\
\text { Planni } \\
\text { ng }\end{array}$ & 5 & 4 & 80 & 1 & 20 \\
\hline \multicolumn{2}{|c|}{ Total } & 15 & 13 & $\begin{array}{l}86 \\
, 6 \\
7\end{array}$ & 2 & $\begin{array}{c}13,3 \\
3\end{array}$ \\
\hline
\end{tabular}

Source: Research data analysed in 2017

The implementation of the assessment planning in this phase based on Table 3.3 can be evaluated and analysed as follows:

a. The evaluation result of attitude assessment implementation obtained $80 \%$ or 4 indicators of this assessment were implemented by the teachers, and $20 \%$ or 1 indicator was not yet implemented by the teachers stating that technique used in the assessment process should be informed well.

b. The evaluation result of knowledge assessment implementation obtained $100 \%$, indicated that all indicators of this assessment were implemented by the teachers. c. The evaluation result of skill assessment implementation obtained $80 \%$ or 4 indicators of this assessment were implemented by the teachers, and $20 \%$ or 1 indicator was not implemented by the teachers stating that daily test should be done periodically after teaching one or more basic competence in order to measure the achievement of the competence.

The evaluation result of the assessment planning implementation in this phase based on table 3.3 generally indicated that $86.67 \%$ or 13 indicators were implemented by the teachers, and $13.33 \%$ or 2 indicators were not yet implemented by the teachers.

\section{Achievement Level Category of Authentic Assessment Implementation}

The achievement level of this assessment implementation were categorized into 4 categories; excellent, good, fair, and poor. Each category was indicated by the percentage obtained from the average score. Each evaluated indicator was rated on a scale of 1 to 4. More detailed data can be seen in Table 3.4. Table 3.4. Achievement Level of the Implementation in Process Phase (Transaction Phase)

\begin{tabular}{|c|l|c|c|c|c|}
\hline No. & $\begin{array}{c}\text { Evaluation } \\
\text { Components }\end{array}$ & $\begin{array}{c}\text { Number of } \\
\text { Indicators }\end{array}$ & $\begin{array}{c}\text { Obtain } \\
\text { ed } \\
\text { Total } \\
\text { Score }\end{array}$ & $\begin{array}{c}\text { Ave } \\
\text { rage } \\
\text { Scor } \\
\mathrm{e}\end{array}$ & Category \\
\hline 1 & $\begin{array}{l}\text { Attitude } \\
\text { Assessment } \\
\text { Planning }\end{array}$ & 5 & 16 & 3,2 & Good \\
\hline 2 & $\begin{array}{l}\text { Knowledge } \\
\text { Assessment } \\
\text { Planning }\end{array}$ & 5 & 20 & 4 & Excellent \\
\hline 3 & $\begin{array}{l}\text { Skill } \\
\text { Assessment } \\
\text { Planning }\end{array}$ & 5 & 16 & 3,2 & Good \\
\hline \multicolumn{7}{|c|}{ Process Phase } & $\mathbf{1 5}$ & $\mathbf{5 2}$ & $\mathbf{3 , 4 7}$ & Good \\
\hline
\end{tabular}

Source: Research data analysed in 2017

The achievement level category of the assessment in this phase based on table 3.2 can be explained as follows:

a. Achievement level of attitude assessment implementation conducted by the teachers in this phase obtained a total score of 16 of 5 indicators with an average score of 3.2 which belonged to good category.

b. Achievement level of knowledge assessment implementation conducted by the teachers in this phase obtained a total score of 20 of 5 indicators with an average score of 4 which belonged to excellent category.

c. Achievement level of skill assessment implementation in this phase obtained a total score of 16 of 5 indicators with an average score of 3.2 which belonged to good category.

Achievement level of the assessment implementation in this phase based on Table 3.4 obtained a total score of 52 of 15 indicators with an 
average score of 3.47 which belonged to good category.

\section{Outcomes Phase of Evaluation (Outcomes Phase) 1. Evaluation of Authentic Assessment Management Implementation}

Description of the implementation of this assessment was obtained through document analysis by comparing several indicators that did not yet conform to the standards. More detailed data can be seen in Table 3.5.

Table 3.5. Evaluation of the Implementation of Stake Model Authentic Assessment Management in Outcomes Phase

\begin{tabular}{|c|c|c|c|c|c|c|}
\hline \multirow{3}{*}{$\begin{array}{l}\text { Evaluatio } \\
\text { n Phase }\end{array}$} & \multirow{3}{*}{$\begin{array}{l}\text { Evaluati } \\
\text { on } \\
\text { Compon } \\
\text { ents }\end{array}$} & \multirow{3}{*}{$\begin{array}{c}\text { Number } \\
\text { of } \\
\text { Indicator } \\
\mathrm{s}\end{array}$} & \multicolumn{4}{|c|}{ Implementation } \\
\hline & & & \multicolumn{2}{|c|}{ Proper } & \multicolumn{2}{|c|}{ Improper } \\
\hline & & & $\begin{array}{l}\text { To } \\
\text { tal }\end{array}$ & $\%$ & Total & $\%$ \\
\hline \multirow[t]{3}{*}{$\begin{array}{l}\text { Outcom } \\
\text { es } \\
\text { Phase }\end{array}$} & $\begin{array}{l}\text { Attitude } \\
\text { Assessm } \\
\text { ent } \\
\text { Planning }\end{array}$ & 7 & 5 & $\begin{array}{c}71,4 \\
3\end{array}$ & 2 & $\begin{array}{c}28,5 \\
7\end{array}$ \\
\hline & $\begin{array}{l}\text { Knowled } \\
\text { ge } \\
\text { Assessm } \\
\text { ent } \\
\text { Planning }\end{array}$ & 8 & 8 & 100 & 0 & 0 \\
\hline & $\begin{array}{l}\text { Skill } \\
\text { Assessm } \\
\text { ent } \\
\text { Planning }\end{array}$ & 8 & 6 & 75 & 2 & 25 \\
\hline \multicolumn{2}{|c|}{ Total } & 23 & 19 & $\begin{array}{c}82,6 \\
1\end{array}$ & 4 & $\begin{array}{c}17,3 \\
9\end{array}$ \\
\hline \multicolumn{2}{|c|}{$\begin{array}{l}\text { Authentic Assessment } \\
\text { Implementation }\end{array}$} & 72 & 61 & $\begin{array}{c}84,7 \\
2\end{array}$ & 11 & $\begin{array}{c}15,2 \\
8\end{array}$ \\
\hline
\end{tabular}

Source: Research data analysed in 2017

The implementation of the assessment management in this phase based on Table 3.5 can be explained as follows:

a. Evaluation result of the implementation of attitude assessment management obtained $71,43 \%$ or 5 indicators of the assessment management were implemented by the teachers, and $28,57 \%$ or 2 indicators were not implemented yet by the teachers. The unimplemented indicators were: (1) the attitude assessment data should come from various attitude assessment techniques and instruments, and (2) the result of the assessment analysis should be returned to students with feedback.

b. The evaluation result of knowledge assessment management obtained $100 \%$ indicated that all the indicators of this assessment management were implemented by the teachers.

c. The evaluation result of the implementation of skill assessment management obtained $75 \%$ or 6 indicators of this assessment management were implemented by the teachers, and $25 \%$ or 2 indicators were not yet implemented by the teachers. The unimplemented indicators were: (1) the skill assessment result should be reported to the students after the assessment process completed periodically, and (2) the assessment result should have further analysis to determine progress and learning difficulties and returned to students with the feedback written in the form of educational comments.

The evaluation result of the assessment management in this phase generally showed that $84.72 \%$ or 61 indicators were implemented by the teachers, and $15.28 \%$ or 11 indicators were not yet implemented by the teachers.

\section{Achievement Level Category of Authentic Assessment Management}

Achievement level of this assessment management were categorized into 4 categories: excellent, good, fair, and poor. Each category was indicated by the percentage obtained from the average score. Each evaluated indicator was rated on a scale of 1 to 4. More detailed data can be seen in Table 3.6.

Table 3.6. Achievement Level of the Implementation in Outcomes Phase

\begin{tabular}{|c|l|c|c|c|c|}
\hline No & \multicolumn{1}{|c|}{$\begin{array}{c}\text { Evaluation } \\
\text { Components }\end{array}$} & $\begin{array}{c}\text { Numb } \\
\text { er of } \\
\text { Indica } \\
\text { tors }\end{array}$ & $\begin{array}{c}\text { Obtain } \\
\text { Total } \\
\text { Score }\end{array}$ & $\begin{array}{c}\text { Ave } \\
\text { rage } \\
\text { Scor } \\
\text { e }\end{array}$ & $\begin{array}{c}\text { Categ } \\
\text { ory }\end{array}$ \\
\hline 1 & $\begin{array}{l}\text { Attitude } \\
\text { Assessment } \\
\text { Planning }\end{array}$ & 7 & 20 & 2,86 & Good \\
\hline 2 & $\begin{array}{l}\text { Knowledge } \\
\text { Assessment } \\
\text { Planning }\end{array}$ & 8 & 32 & 4 & $\begin{array}{l}\text { Excelle } \\
\text { nt }\end{array}$ \\
\hline 3 & $\begin{array}{l}\text { Skill Assessment } \\
\text { Planning }\end{array}$ & 8 & 24 & 3 & Good \\
\hline \multicolumn{2}{|l}{ Outcomes Phase } & $\mathbf{2 3}$ & $\mathbf{7 6}$ & $\mathbf{3 , 2 9}$ & Good \\
\hline
\end{tabular}

Source: Research data analysed in 2017

The achievement level category of this assessment management in outcomes phase based on table 3.6 can be explained, as follows:

a. Achievement level of attitude assessment management conducted by the teachers in this phase obtained a total score of 20 of 7 indicators with an average score of 2.86 which belonged to good category.

b. Achievement level of knowledge assessment management conducted by the teachers in this phase obtained a total score of 32 of 8 indicators with an average score of 4 which belonged to excellent category.

c. Achievement level of skill assessment management conducted by the teacher in this phase obtained a total score of 24 of 8 indicators with an average score of 3 which belonged to good category.

Based on table 3.6 above, the achievement level of the assessment management in this phase obtained a total score of 76 of 23 indicators with an average score of 3.29 which belonged to good category. 


\section{Obstacles in the Implementation of Authentic Assessment}

The results of interviews done to social science teachers of SMP Negeri 2 Purwokerto related to some obstacles in the implementation of authentic assessment were as follows:

Obstacles in authentic assessment planning were a complex authentic assessment planning and lack of understanding in making good and correct assessment instruments. A complex assessment plan existed because of the large number of assessment components that must be planned before the implementation of the assessment. Another obstacle in this assessment was the lack of understanding of this assessment and the lack of authentic assessment guidebooks availability. This obstacle appeared because the training followed gave less impact to the teachers and the material provided in the training was less profound.

The obstacle found in the implementation of this assessment was that there were many components that must be controlled simultaneously including students' activity in mastering the knowledge, attitude and skill improvement that can be performed. In the attitude assessment, teachers should assess as detailed as possible the students' behaviour and attitude simultaneously while there were quite large number of students in the class. In addition, the task of teachers was quite heavy. Teachers must be careful in recognizing each student in the classroom. The attitude assessment aspects, considered as the obstacles of the assessment for the teachers, had some elements such as, the value of discipline, cooperation and respect for other people opinions. Such an assessment led to unreal attitude assessment. In this case, the benchmark of score difference was only based on good and poor students in that class, while the other students obtained standard score. In addition, in terms of skill, the teachers must conduct observation and portfolio of activities and knowledge assessment done to the students such as understanding the material, understanding and presenting the material. Thus, there were score of students' presentations and tasks.

The obstacles found in the management assessment was the complex of the score calculation and recap process of students' learning outcomes. The calculation should be done by the teachers based on the correct scoring guidelines and assessment rubric. The score calculation of students' learning outcomes consisted of 3 aspects; attitude, knowledge, and skills. Teachers recapped the students score manually so it took accuracy and precision.

Solutions offered to overcome the obstacles in authentic assessment are as follows:

1. Make detailed and careful assessment planning so that no points of the indicators are missed in the assessment.
2. Create an assessment rubric with clear criteria and scoring rubric so it may prevent students from confusion.

3. Select techniques that facilitate teachers to conduct the assessment more easily although they have many components to assess. Some of the techniques offered are as follows:

a. Teachers should always hold the assessment sheets at the time of teaching, and determine the components of competence that will be assessed before the teaching begins.

b. If teachers need to assess some competencies at each meeting, then it can be arranged by limiting the number of the students that will be assessed.

c. Collaborate with other social science teachers by conducting Classroom Action Research (PTK).

4. Use the assessment format in excel program that facilitates teachers to calculate and recap the students' score automatically.

\section{References}

Hosnan, M. (2014). Pendekatan Saintifik dan Kontekstual dalam Pembelajaran Abad 21: KunciSuksesImplementasiKurikulum 2013.Bogor: Ghalia Indonesia.

ImasKurinasihdanBerlinSani.(2014).ImplementasiKuri kulum2013: Konsep dan Penerapan. Surabaya: KataPena.

Kemendikbud. Permendikbud Nomor 66Tahun 2013Tentang Standar Penilaian Pendidikan. http://akhmadsudrajat.files.wordpress.com. diunduh tanggal27Maret2014.

Kementerian Pendidikan dan Kebudayaan. (2014). Ilmu Pengetahuan Sosial : buku guru. Jakarta: Kementerian Pendidikan dan Kebudayaan.

Kementerian Pendidikan dan Kebudayaan. (2014). Ilmu Pengetahuan Sosial : buku guru. Jakarta: Kementerian Pendidikan dan Kebudayaan.

Kusnandar. (2013). PenilaianAutentik(Penilaian Hasil BelajarPeserta DidikBerdasarkanKurikulum2013).Jakarta:Raja GrafindoPersada.

Peraturan Menteri Pendidikan dan Kebudayaan Republik Indonesia Nomor 68 Tahun 2013 tentang Standar Kerangka Dasar dan Struktur Kurikulum Sekolah Menengah Pertama/Madrasah Tsanawiyah.

Purwanti, Ela. (2014). Evaluasi Pelaksanaan Penilaian Autentik Dalam Pembelajaran Ekonomi Sesuai Kurikulum 2013diSMA Negeri2 Ngaglik. Skripsi. Yogyakarta: Universitas Negeri Yogyakarta. 
Udin Syaefudin Sa'ud. (2013). Inovasi Pendidikan. Bandung: Alfabeta.

YuliSetyo Dewi, Penerapan Autenthic Assement Untuk Meningkatkan Spatial Ability dan HasilBelajar Siswa Pada PembelajaranGeografi Materi Hubungan Manusiad an Lingkungan Akibat Dinamikan Hidrosferdi Kelas IPS1SMA 7 Surakarta. Jurnal Pendidikan Geografi. Volume3No1 